\title{
Ozone and 1-Methylcyclopropene Alter the Postharvest Quality of Broccoli
}

\author{
Charles F. Forney, ${ }^{1}$ Jun Song, Lihua Fan, Paul D. Hildebrand, and Michael A. Jordan \\ Agriculture and Agri-Food Canada, Atlantic Food and Horticulture Research Centre, 32 Main St., \\ Kentville, N.S., B4N 1J5, Canada
}

\begin{abstract}
AdDitional INDEX wORDS. Brassica oleracea, respiration, ethylene production, volatiles, color, chlorophyll fluorescence
Abstract. Fresh broccoli (Brassica oleracea $\mathrm{L}$. Italica group) florets untreated or treated with $1 \mu \mathrm{L} \cdot \mathrm{L}^{-1} \mathbf{1}$-methylcyclopropene (1-MCP) for $14 \mathrm{~h}$, were stored at $12{ }^{\circ} \mathrm{C}$ with 0,200 , or $700 \mathrm{~nL} \cdot \mathrm{L}^{-1}$ ozone. Senescence parameters were evaluated after $0,1,2,5,8$, or 12 days of storage. Treatment with 1-MCP delayed the yellowing of florets, and at day 5 the hue angle of 1-MCP treated florets was $116^{\circ}$ (green) compared to $102^{\circ}$ (yellow) for the control. Respiration rates of florets were reduced by 1-MCP for the first 5 days. The 1-MCP treatment maintained higher chlorophyll fluorescence expressed as $F_{v} / F_{m}$ during 12 days of storage. Also, 1-MCP reduced dimethyl trisulfide production, which contributes to off-odor development in broccoli florets. Compared with the controls, florets stored in $200 \mathrm{~nL} \cdot \mathrm{L}^{-1}$ ozone had less mold growth and yellowed more slowly, but no differences were observed in respiration, ethylene production, or $\mathbf{F}_{\mathrm{v}} / \mathbf{F}_{\mathrm{m}}$. Florets stored in $700 \mathrm{~nL} \cdot \mathrm{L}^{-1}$ ozone were greener than florets held in air or $200 \mathrm{~nL} \cdot \mathrm{L}^{-1}$ ozone. Interestingly, chlorophyll fluorescence of the florets stored in $700 \mathrm{~nL} \cdot \mathrm{L}^{-1}$ ozone decreased significantly and at day $12, F_{v} / F_{m}$ was only $30 \%$ of its initial value. Ozone at $700 \mathrm{~nL} \cdot \mathrm{L}^{-1}$ stimulated respiration and ethylene production of florets after 1 day of storage, and caused visible damage in the form of increased weight loss and browning of the floret stem ends. Treatment of broccoli with 1-MCP alone or in combination with $200 \mathrm{~nL} \cdot \mathrm{L}^{-1}$ ozone maintained the quality and extended the shelf life of broccoli florets.
\end{abstract}

Broccoli (Brassica oleracea L. Italica group) is a popular vegetable with high nutritional value and health benefits. The floral heads of broccoli plants are composed of florets, and each floret consists of a group of immature flower buds with chlorophyll-containing sepals. However, broccoli is a highly perishable vegetable that senesces quickly after harvest (King and Morris, 1994). When held at ambient temperatures, broccoli turns yellow and becomes unmarketable within $3 \mathrm{~d}$ (Gnanasekharan, et al., 1992; Wang and Hruschka, 1977), and after 6 d chlorophyll levels fall by more than $90 \%$ and protein levels by over $70 \%$ (Page et al., 2001). Refrigeration is the primary means of slowing the rate of senescence and maintaining broccoli quality. At $2.5^{\circ} \mathrm{C}$, broccoli remains in good condition for up to 3 weeks of storage (Ryall and Lipton, 1979). Modified atmosphere packaging (MAP) and controlled atmosphere (CA) storage can also extend the storage life of broccoli (Barth et al., 1993; Lipton and Harris, 1974). Storage in controlled atmospheres consisting of $6 \% \mathrm{CO}_{2}$ and $2 \% \mathrm{O}_{2}$ delays yellowing, prolongs chlorophyll retention, reduces mold development, and prevents the formation of offensive odors (Bastrash et al., 1993). However, atmosphere modification requires specialized storage facilities or packaging, achieving and maintaining specific conditions can be difficult due in part to high rates of respiration and inherent variability, and the beneficial effect is lost when broccoli is removed from the storage atmosphere. Heat treatment alters senescence by affecting the rates of chlorophyll fluorescence loss, ethylene synthesis, respiration, protein degradation, decay, water loss, and yellowing (Forney, 1995; Tian et al., 1997), but this technique has had limited commercial application.

The sensitivity of broccoli to ethylene plays an important role in senescence (Tian et al., 1994). 1-Methylcyclopropene (1-MCP),

Received for publication 24 June 2002. Accepted for publication 11 Feb. 2003. Contribution No. 2251 of the Atlantic Food and Horticulture Research Centre, Agriculture and Agri-Food Canada. The authors thank Daniel A.J. Ryan for statistical design, Carolyn Domytrak for technical assistance, and John DeLong and Peter Hicklenton for their helpful suggestions in preparing the manuscript.

'Corresponding author;email forneyc@agr.gc.ca. an ethylene action inhibitor, delays the onset of yellowing and significantly extends the storage life of broccoli (Fan and Mattheis, 2000; Ku and Wills, 1999). Ozone, the tri-atomic form of oxygen, is a strong antimicrobial agent with numerous potential applications in the food industry (Kim et al., 1999). Studies indicate that ozone can cause various physiological changes in plants including the induction of defense systems against oxidative stress (Pell et al., 1997). The application of ozone can be effective in reducing decay of fruits and vegetables (Hildebrand et al., 2001; Song et al., 2000) and yellowing in stored broccoli (Skog and Chu, 2001). However, the physiological and biochemical changes related to these effects have not been examined.

The objective of this study was to evaluate the potential of 1-MCP and ozone in prolonging broccoli storage life based on color, decay, fresh weight loss, respiration, ethylene production, chlorophyll fluorescence, and volatile compound production.

\section{Materials and Methods}

Plant materials. Heads of fresh broccoli (cvs. Everest and Regal) grown commercially in the Annapolis Valley, Nova Scotia, Canada were obtained on the day of harvest from a packinghouse and transported to the laboratory within $3 \mathrm{~h}$. Decay-free heads were selected and divided with a sharp knife into florets weighing $\approx 15$ $\mathrm{g}$ each. About $150 \mathrm{~g}$ of florets were placed in plastic pint-sized clamshell containers and weighed. Three clamshell containers with lids open were used for each treatment-removal combination. The experiment was replicated three times with broccoli harvested on three different dates each $\approx 2$ weeks apart.

1-MCP TREATMENT. At each harvest, broccoli florets were divided into two groups. Each group was placed in a 128-L stainless steel container and held at $10^{\circ} \mathrm{C}$. $1-\mathrm{MCP}$ at a concentration of $\approx 1.0 \mu \mathrm{L} \cdot \mathrm{L}^{-1}$ was generated in one of the containers by mixing $1.1 \mathrm{~g}$ Ethylblock with a reaction buffer, which were gifts from BioTechnologies for Horticulture Inc. (Walterboro, S.C.). The weight of Ethylblock used was based on the percent a.i.listed on the label. The container was sealed for $14 \mathrm{~h}$, and then ventilated with air for $2 \mathrm{~h}$. The second container served as a control receiv- 
ing no 1-MCP. Hydrated lime was placed in both containers to prevent the accumulation of $\mathrm{CO}_{2}$.

OzONE TREATMENT. After the 1-MCP treatment, all florets were stored in experimental chambers at $12 \pm 0.5{ }^{\circ} \mathrm{C}$ with $95 \%$ to $98 \%$ relative humidity for up to $12 \mathrm{~d}$. Three treatment chambers $\left(5.2 \mathrm{~m}^{3}\right)$ constructed of wooden frames lined with 6-mil $(0.15-$ $\mathrm{mm}$ ) polyethylene film, were situated in each of three walk-in environmental chambers (model GR36; Econaire Systems Ltd., Winnipeg, Man.). Ozone concentrations of $200 \pm 10$ and $700 \pm$ $20 \mathrm{~nL} \cdot \mathrm{L}^{-1}$ were maintained in two of the chambers by using ozone generators (model SF 300; Aqua-air, Simpson Environmental Corp., Mississauga, Ont.) and small air circulating fans. Ozone concentration in each chamber was continuously monitored with an ozone analyzer (model 1180; Dasibi Environmental Corp. Galendale, Calif.) and maintained with a data logger (model 21X; Campbell Scientific Inc., Logan, Utah) connected to an electronic relay that turned the generator on or off in conjunction with programmed ozone set points. The third chamber had no ozone generator and was equipped with only a circulating fan to comprise the $0 \mathrm{~nL} \cdot \mathrm{L}^{-1}$ ozone treatment. Broccoli florets receiving no $1-\mathrm{MCP}$ treatment and stored in the $0 \mathrm{~nL} \cdot \mathrm{L}^{-1}$ ozone treatment were considered as the controls. Temperature and $\mathrm{RH}$ in each chamber were recorded continuously on the data logger at 1 min intervals using temperature and humidity probes (Model HMP45C, Campbell Scientific Inc., Logan, Utah). To avoid confounding effects of the three chambers with the ozone treatments, each ozone treatment $\left(0,200\right.$, and $\left.700 \mathrm{~nL} \cdot \mathrm{L}^{-1}\right)$ was conducted in a different chamber for each of the three replications.

Quality EVAluation. Floret samples were taken after 0, 1 , $2,5,8$, and $12 \mathrm{~d}$ of exposure to ozone and evaluated for color, fresh weight loss, $\mathrm{CO}_{2}$ production, $\mathrm{O}_{2}$ consumption, respiration quotient (RQ), ethylene production, chlorophyll fluorescence, and volatile production. Observations on the presence of mold and decay of flower buds and discoloration of cut stems were also made at each evaluation.

Color. Color of broccoli florets was measured using a Minolta Chromameter200 (MinoltaCameraCo., Osaka, Japan) equipped with an 8-mm measuring aperture and calibrated with a white standard tile. $\mathrm{L}^{*}$ (Lvalue), $\mathrm{C}^{*}$ (chroma), and $\mathrm{H}^{\circ}$ (hue angle) were recorded. Color readings were obtained by placing the aperture against the flower buds in the center of three florets from each of the three clamshell containers from each treatment. Hue angle was used to express color change, where values of $120^{\circ}$ to $130^{\circ}$ indicate green and $<110^{\circ}$ yellow (Forney, 1995; Gnanasekharan et al., 1992).

RESPIRATION, RQ, AND ETHYLENE PRODUCTION. One clamshell of broccoli florets $(\approx 150 \mathrm{~g})$ from each treatment was warmed to 20 ${ }^{\circ} \mathrm{C}$ and sealed in a 1-L glass jar for $1 \mathrm{~h}$. A $10 \mathrm{~mL}$ sample of head space was taken and injected into a gas chromatograph (series 580; Gow-MAC, Bridgewater, N.J.) equipped with a 2-mL sample loop, CTR I column (Alltech, Deerfield, Ill.) and thermal conductivity detector to determine $\mathrm{CO}_{2}$ production and $\mathrm{O}_{2}$ consumption. The temperatures of the injector, column, and detector were 40, 40, and $70{ }^{\circ} \mathrm{C}$, respectively, and helium was used as the carrier gas with a flow rate of $60 \mathrm{~mL} \cdot \mathrm{min}^{-1}$. The RQ was calculated. A $1-\mathrm{mL}$ sample of head space was then analyzed for ethylene on a gas chromatograph (Carle Instuments, Inc., Anaheim, Calif.) equipped with a $1.9 \mathrm{~m} \times 3.2 \mathrm{~mm}$ (o.d.) activated alumina column with a helium carrier gas flow of $50 \mathrm{~mL} \cdot \mathrm{min}^{-1}$ and a flame ionization detector. The temperature of the injector, detector, and column was $70^{\circ} \mathrm{C}$. Concentrations of $\mathrm{CO}_{2}, \mathrm{O}_{2}$, and ethylene in the samples were quantified using external standards.

Chlorophyll Fluorescence. Chlorophyll fluorescence was determined using a modulated fluorometer (model OS-500; OptiScience, Tyngsboro, Mass.). Three clamshell containers of florets from each treatment were sampled and fluorescence measurements were made in a darkened laboratory. The fluorometer was operated in the $\mathrm{F}_{\mathrm{v}} / \mathrm{F}_{\mathrm{m}}$ mode and fluorescence was measured using a photodiode in the 710 to $760 \mathrm{~nm}$ range. The fluorometer probe was placed firmly on the broccoli flower buds and a pulse of 10 $\mathrm{mmol} \cdot \mathrm{m}^{-2} \cdot \mathrm{s}^{-1}$ light was applied for $0.8 \mathrm{~s}$. Fluorescence parameters of minimal fluorescence $\left(\mathrm{F}_{\mathrm{o}}\right)$, maximal fluorescence $\left(\mathrm{F}_{\mathrm{m}}\right)$, and photochemical efficiency $\left(\mathrm{F}_{\mathrm{v}} / \mathrm{F}_{\mathrm{m}}\right.$, where $\left.\mathrm{F}_{\mathrm{v}}=\mathrm{F}_{\mathrm{m}}-\mathrm{F}_{\mathrm{o}}\right)$ were recorded from the fluorometer digital display. Readings were taken from three florets in each container and averaged.

VolatiLE ANALYSIS. One clamshell of broccoli florets $(\approx 150$ g) from each treatment was sealed in a 1-L glass jar with a Teflon lid and allowed to equilibrate for $1 \mathrm{~h}$ at $20^{\circ} \mathrm{C}$ under a flow of 100 $\mathrm{mL} \cdot \mathrm{min}^{-1}$ of purified air. A $100-\mathrm{mL}$ head space sample was then trapped onto $120 \mathrm{mg}$ Tenax GR 20/35 (Alltech Associates, Inc., Deerfield, Ill.) in a $100 \times 6.4$-mm (o.d.) glass tube. Samples were analyzed on a Magnum gas chromatograph-mass spectrometer (GC-MS) system (Finnigan MAT, San Jose, Calif.) equipped with a LSC 2000 purge and trap concentrator (Tekmar, Cincinnati). Volatile analysis and quantification methods used were described by Forney and Jordan (1998).

Statistical Analysis. The experimental design was a completely randomized factorial with two 1-MCP treatments (with or without 1 -MCP), three ozone treatments $\left(0,200\right.$, and $\left.700 \mathrm{~nL} \cdot \mathrm{L}^{-1}\right)$, six evaluation times $(0,1,2,5,8$, and $12 \mathrm{~d})$ and three replications. Data were analyzed using the analysis of variance (ANOVA) directive and LSD option of Genstat 5 (Genstat 5 Committee, 1993).

\section{Results}

CoLor. 1-MCP reduced yellowing in fresh broccoli florets as shown by hue angle (Fig. 1). Initially, the hue angle of florets averaged $131^{\circ}$, but as florets yellowed, hue angles of the control florets decreased to $102^{\circ}, 89^{\circ}$, and $85^{\circ}$ after 5,8 , and $12 \mathrm{~d}$, respectively. The 1-MCP treatment delayed the yellowing of florets; the hue angle was still $116^{\circ}$ after $5 \mathrm{~d}$. Visible yellowing was not observed in 1-MCP treated florets until $8 \mathrm{~d}$. Delayed yellowing was also found in florets treated with $700 \mathrm{~nL} \cdot \mathrm{L}^{-1}$ ozone without 1-MCP. After $5 \mathrm{~d}$, florets held in $700 \mathrm{~nL} \cdot \mathrm{L}^{-1}$ ozone had a hue angle of $115^{\circ}$. Although sepals of the floral buds remained green for 12 $\mathrm{d}$ when treated with $700 \mathrm{~nL} \cdot \mathrm{L}^{-1}$ ozone, they appeared desiccated and the stem ends turned brown. Yellowing of florets treated with $200 \mathrm{~nL} \cdot \mathrm{L}^{-1}$ ozone was delayed slightly, but no browning of stem ends was observed.

DECAY. Small patches of mold growth, observed as superficial mycelium on the sepals of flower buds, was reduced or eliminated on florets exposed to 200 or $700 \mathrm{~nL} \cdot \mathrm{L}^{-1}$ ozone, compared with the control treatment (data not shown). The 1-MCP treatment without ozone had no effect on mold growth. No other form of decay was observed on florets in any of the treatments.

FrESH WEIGHT LOSS. The $700 \mathrm{~nL} \cdot \mathrm{L}^{-1}$ ozone treatment increased the rate of weight loss in broccoli florets. After $12 \mathrm{~d}$ of storage, florets held in $700 \mathrm{~nL} \cdot \mathrm{L}^{-1}$ ozone without prior $1-\mathrm{MCP}$ treatment lost $24 \%$ of their initial weight, compared with $15 \%$ for florets from both the 0 and $200 \mathrm{~nL} \cdot \mathrm{L}^{-1}$ ozone treatments (data not shown). The 1-MCP treatment had no effect on the weight loss of the broccoli florets stored with 0 and $200 \mathrm{~nL} \cdot \mathrm{L}^{-1}$ ozone. However, it significantly reduced the weight loss of florets held in $700 \mathrm{~nL} \cdot \mathrm{L}^{-1}$ ozone to $19 \%$ after $12 \mathrm{~d}$.

RESPIRATION, RQ, AND ETHYLENE PRODUCTION. $\mathrm{CO}_{2}$ production 


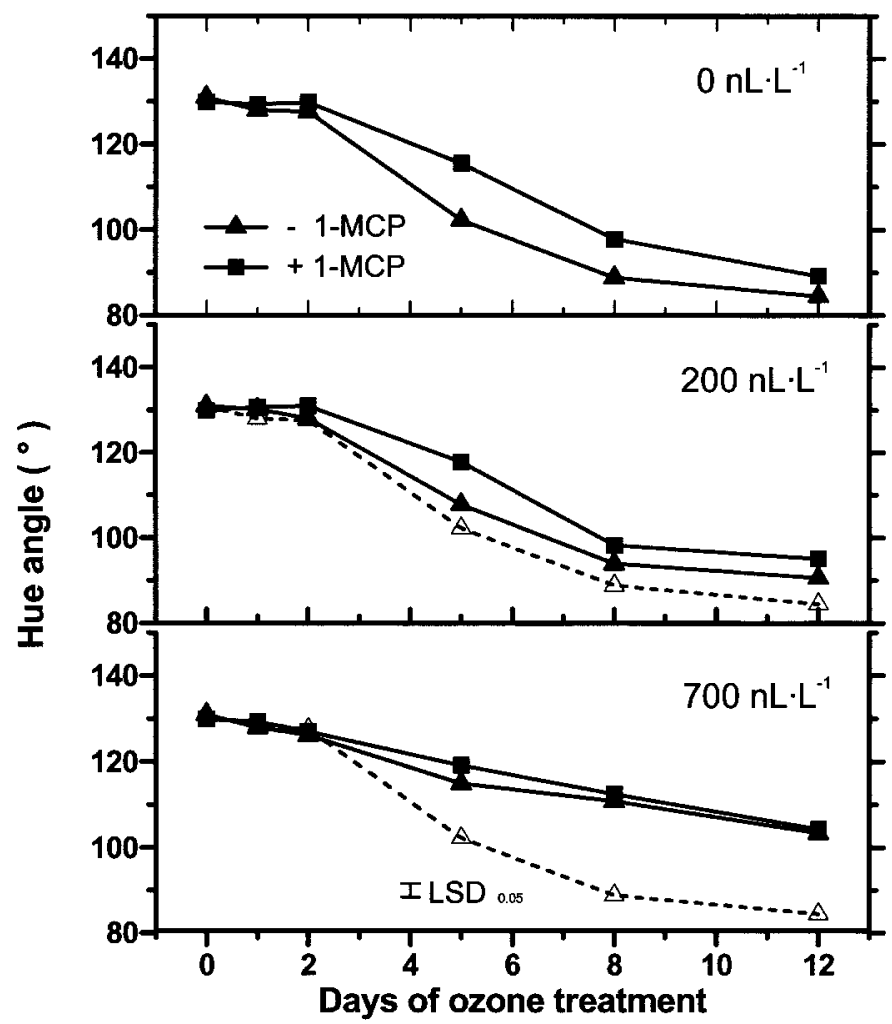

Fig. 1. The hue angle of broccoli florets treated with (+) or without (-) $1 \mu \mathrm{L} \cdot \mathrm{L}^{-1}$ 1-methylcyclopropene (-1-MCP) for $14 \mathrm{~h}$ and held at $12{ }^{\circ} \mathrm{C}$ with 0,200 , or $700 \mathrm{~nL} \cdot \mathrm{L}^{-1}$ ozone for up to $12 \mathrm{~d}$. Each point represents the mean value from 27 florets. The dashed-line represents the control treatment (1-MCP, $0 \mathrm{~nL} \cdot \mathrm{L}^{-1}$ ozone ) for comparison. The vertical bar represents the LSD for comparison of means within the figure.

by the control broccoli florets increased and peaked at $5 \mathrm{~d}$ and then decreased to a low of $82 \mathrm{~mL} \cdot \mathrm{kg}^{-1} \cdot \mathrm{h}^{-1}$ at $12 \mathrm{~d}$ (Fig. 2). $\mathrm{CO}_{2}$ production was reduced by $1-\mathrm{MCP}$ in florets treated with 0 and $200 \mathrm{~nL} \cdot \mathrm{L}^{-1}$ ozone for the first $5 \mathrm{~d}$ and then reached levels similar to those of the control florets. No significant differences in $\mathrm{CO}_{2}$ production were found in the broccoli florets treated with 200 $\mathrm{nL} \cdot \mathrm{L}^{-1}$ ozone compared with the florets receiving no ozone. However, $\mathrm{CO}_{2}$ production was stimulated immediately after treatment began with $700 \mathrm{~nL} \cdot \mathrm{L}^{-1}$ ozone, and was significantly higher than the controls after 1 and $2 \mathrm{~d}$.

The RQ value of broccoli florets changed during holding at 12 ${ }^{\circ} \mathrm{C}$. The RQ decreased from 1.25 to 1.06 after $5 \mathrm{~d}$, then increased to 1.2 after $12 \mathrm{~d}$. There were no significant effects of $1-\mathrm{MCP}$ or ozone on the RQ value (data not shown).

Ethylene production was not significantly affected by the 1MCP or the $200 \mathrm{~nL} \cdot \mathrm{L}^{-1}$ ozone treatments (Fig. 3). Treatment with $700 \mathrm{~nL} \cdot \mathrm{L}^{-1}$ ozone alone increased ethylene production slightly after 1,2 , and $5 \mathrm{~d}$, but then ethylene production returned to initial levels at $8 \mathrm{~d}$. Exposure to $700 \mathrm{~nL} \cdot \mathrm{L}^{-1}$ ozone stimulated ethylene production by 1-MCP-treated broccoli florets during the first $5 \mathrm{~d}$ peaking at $2 \mathrm{~d}$.

Chlorophyll fluorescence $\left(\mathrm{F}_{\mathrm{v}} / \mathbf{F}_{\mathrm{M}}\right)$. After $5 \mathrm{~d}$, chlorophyll fluorescence was higher in broccoli florets treated with 1-MCP

Fig. 3. Ethylene production rate at $20^{\circ} \mathrm{C}$ of broccoli florets treated with (+) or without (-) $1 \mu \mathrm{L} \cdot \mathrm{L}^{-1} 1$-methylcyclopropene (1-MCP) for $14 \mathrm{~h}$ and held at 12 ${ }^{\circ} \mathrm{C}$ with 0,200 , or $700 \mathrm{~nL} \cdot \mathrm{L}^{-1}$ ozone for up to $12 \mathrm{~d}$. Each point represents the mean rate of three $150 \mathrm{~g}$ samples of florets. The dashed line represents the control treatment $\left(-1-\mathrm{MCP}, 0 \mathrm{~nL} \cdot \mathrm{L}^{-1}\right.$ ozone $)$ for comparison. The vertical bar represents the LSD for comparison of means within the figure.

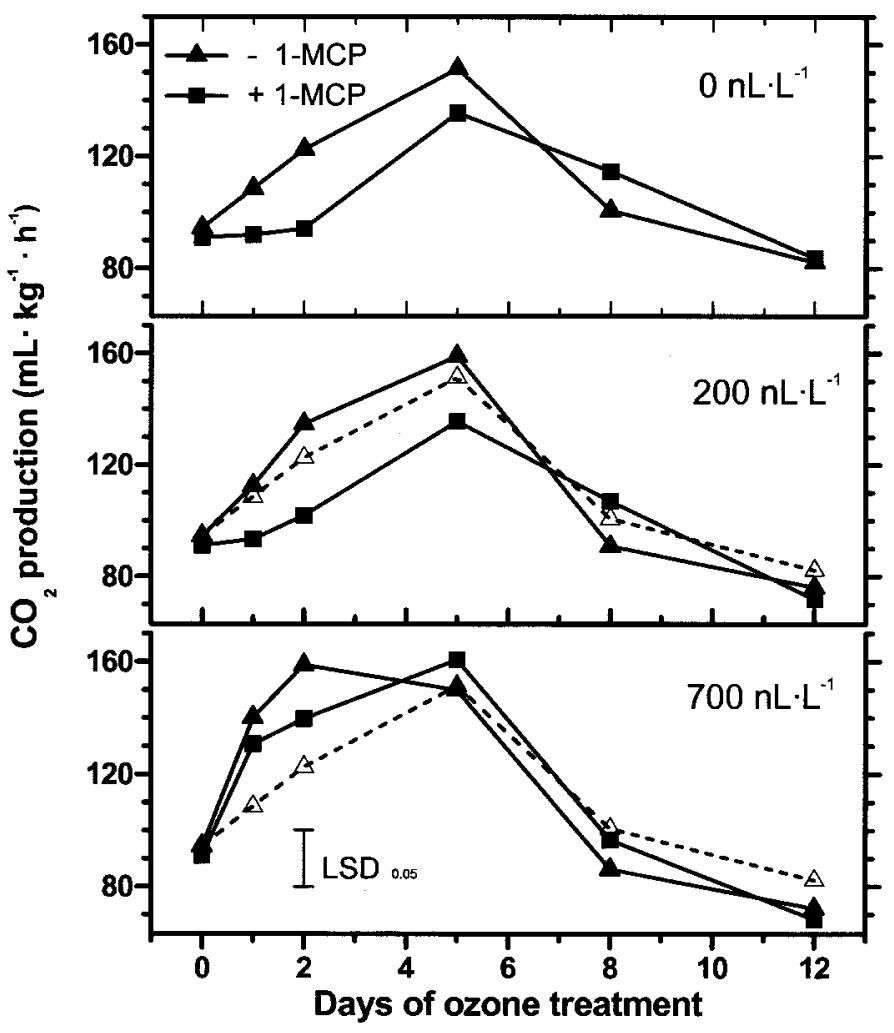

Fig. 2. Respiration rate at $20^{\circ} \mathrm{C}$, measured as $\mathrm{CO}_{2}$ production, of broccoli florets treated with (+) or without (-) $1 \mu \mathrm{L} \cdot \mathrm{L}^{-1} 1$-methylcyclopropene (1-MCP) for $14 \mathrm{~h}$ and held at $12{ }^{\circ} \mathrm{C}$ with 0,200 , or $700 \mathrm{~nL} \cdot \mathrm{L}^{-1}$ ozone for up to $12 \mathrm{~d}$. Each point represents the mean rate of three $150 \mathrm{~g}$ samples of florets. The dashed-line represents the control treatment $\left(-1-\mathrm{MCP}, 0 \mathrm{~nL} \cdot \mathrm{L}^{-1}\right.$ ozone $)$ for comparison. The vertical bar represents the LSD for comparison of means within the figure.

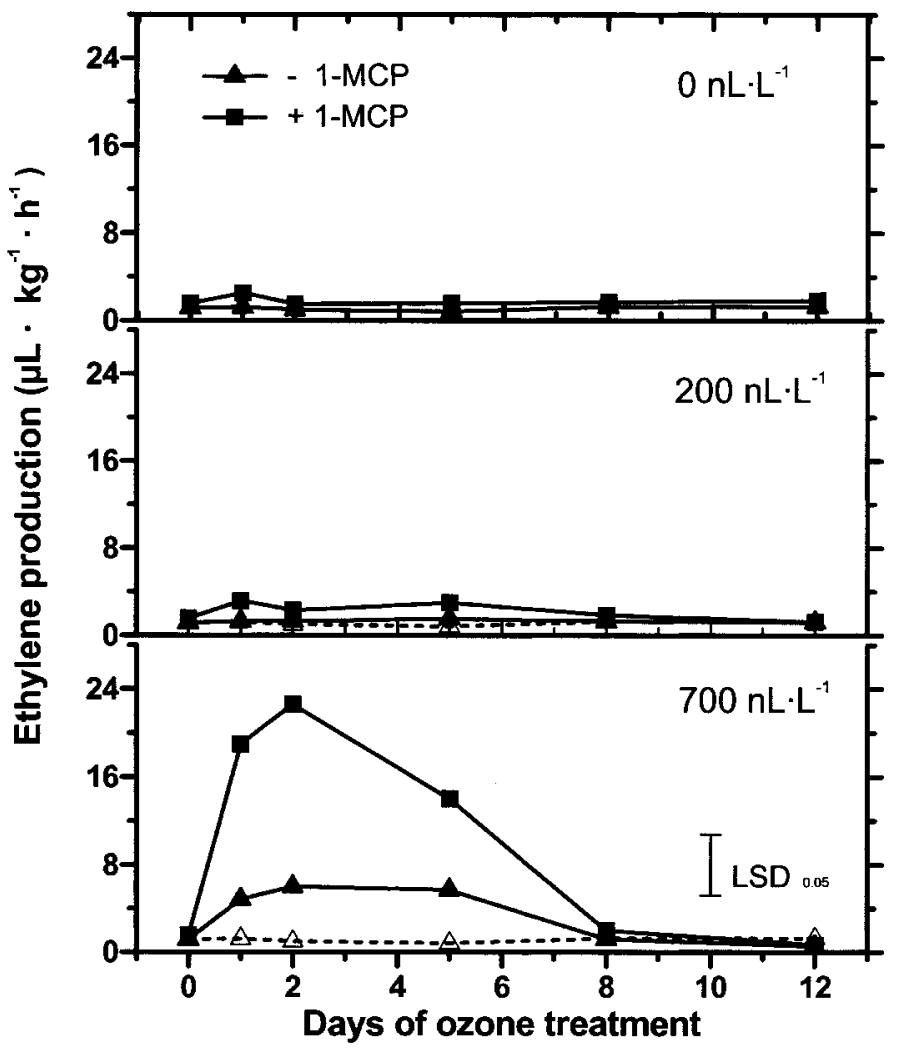




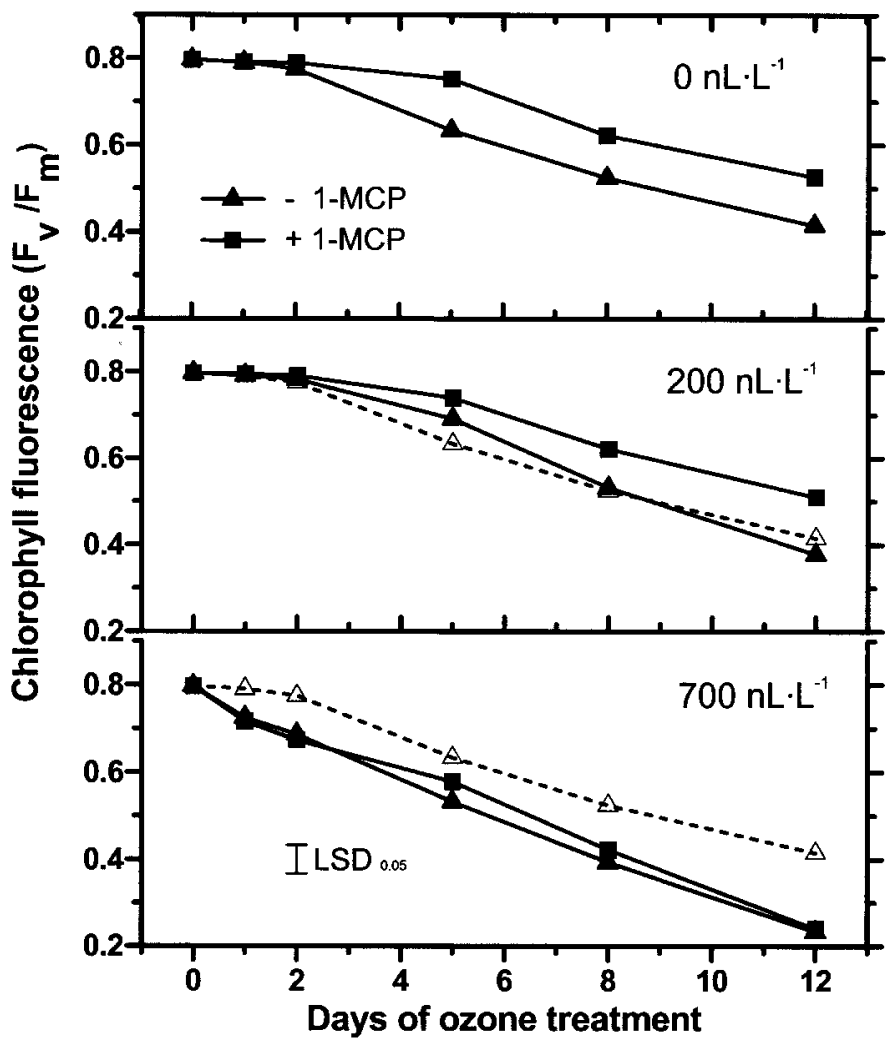

Fig. 4. Chlorophyll fluorescence, expressed as the ratio of $\mathrm{F}_{\mathrm{v}} / \mathrm{F}_{\mathrm{m}}$, of broccoli florets treated with (+) or without (-) $1 \mu \mathrm{L} \cdot \mathrm{L}^{-1} 1$-methylcyclopropene $(1-\mathrm{MCP})$ for $14 \mathrm{~h}$ and held at $12{ }^{\circ} \mathrm{C}$ with 0,200 , or $700 \mathrm{~nL} \cdot \mathrm{L}^{-1}$ ozone for up to $12 \mathrm{~d}$. Each point represents the mean value from 27 florets. The dashed line represents the control treatment $\left(-1-\mathrm{MCP}, 0 \mathrm{~nL} \cdot \mathrm{L}^{-1}\right.$ ozone $)$ for comparison. The vertical bar represents the LSD for comparison of means within the figure.

than in the control (Fig. 4). Chlorophyll fluorescence of the broccoli florets treated with $200 \mathrm{~nL} \cdot \mathrm{L}^{-1}$ ozone alone was similar to the control. However, the $700 \mathrm{~nL} \cdot \mathrm{L}^{-1}$ ozone treatment caused chlorophyll fluorescence of florets to decrease rapidly. 1-MCP did not delay the reduction in chlorophyll fluorescence and after $12 \mathrm{~d}$, chlorophyll fluorescence was only $30 \%$ of its initial value. The $\mathrm{F}_{\mathrm{o}}$ value of all broccoli florets increased for the first $5 \mathrm{~d}$ of storage, but this increase was reduced by the 1-MCP and ozone treatments. $\mathrm{F}_{\mathrm{m}}$ values decreased during storage, with 1-MCP treatment slowing the rate of decrease and $700 \mathrm{~nL} \cdot \mathrm{L}^{-1}$ ozone treatment accelerating it (data not shown).

Volatile PRODUCtion. Postharvest ozone and 1-MCP treatments altered the volatile composition of broccoli florets. Dimethyl trisulfide (DMTS), dimethyl disulfide (DMDS), dimethyl sulfide (DMS), hexen-1-ol, trans-2-hexenal, hexanal, and ethanol were identified and monitored at each sampling. Concentrations of DMTS increased after $8 \mathrm{~d}$ and were significantly reduced by treatment with 1-MCP (Fig. 5). The $700 \mathrm{~nL} \cdot \mathrm{L}^{-1}$ ozone treatment also significantly reduced DMTS production. Data for the other volatiles are not shown. However, dimethyl disulfide increased after $5 \mathrm{~d}$ and the 1-MCP treatment reduced its concentration. Concentration of DMS also increased after $5 \mathrm{~d}$, but was not affected by either 1-MCPor ozone treatment. Hexen-1-ol and trans-2-hexenal increased with storage time but were not detected until after 12 and $8 \mathrm{~d}$, respectively, and 1-MCP reduced their concentrations. Conversely, hexanal concentrations decreased during storage and were no longer detected after $8 \mathrm{~d}$ and were not affected by 1-MCP or ozone treatments. Ethanol concentrations were not affected by storage time, 1-MCP or ozone.

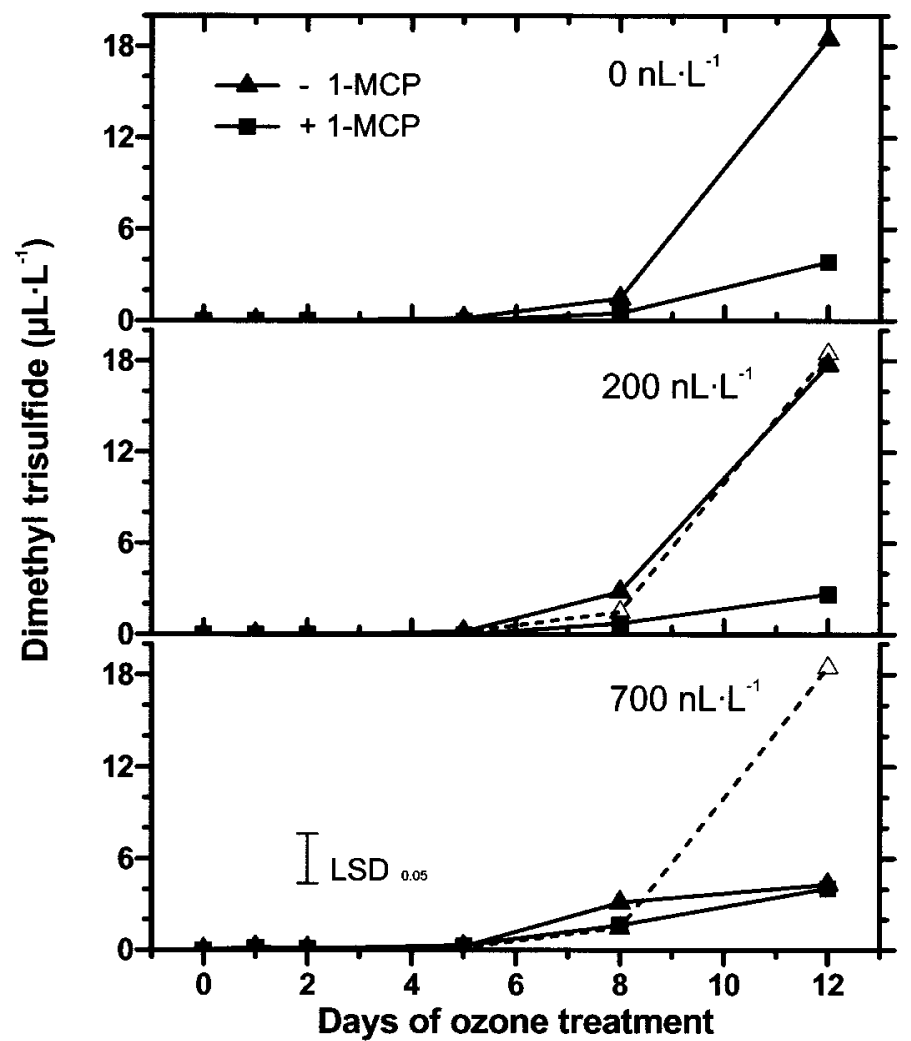

Fig. 5. The headspace concentration of dimethyl trisulfide in $1 \mathrm{Lglass}$ jars containing $150 \mathrm{~g}$ of broccoli florets for $1 \mathrm{~h}$ at $20^{\circ} \mathrm{C}$ under a flow of $100 \mathrm{~mL} \cdot \mathrm{min}^{-1}$ of purified air. Broccoliflorets were treated with (+) or without $(-) 1 \mu \mathrm{L} \cdot \mathrm{L}^{-1} 1$-methylcyclopropene (1-MCP) for $14 \mathrm{~h}$ and held at $12{ }^{\circ} \mathrm{C}$ with 0,200 , or $700 \mathrm{~nL} \cdot \mathrm{L}^{-1}$ ozone for up to $12 \mathrm{~d}$. Each point represents the mean value of 3 jars. The dashed line represents the control treatment $\left(-1-\mathrm{MCP}, 0 \mathrm{~nL} \cdot \mathrm{L}^{-1}\right.$ ozone $)$ for comparison. The vertical bar represents the $\mathrm{LSD}$ for comparison of means within the figure.

\section{Discussion}

One of the major symptoms of senescence of broccoli florets is yellowing, resulting from the degradation of chlorophyll in the sepals (DeEll, et al., 1999; King and Morris, 1994). Ethylene can promote senescence in harvested broccoli and the prevention of its action may prolong broccoli storage life (Fan and Mattheis, 2000; Wills et al., 1999). In our study, 1-MCP, which blocks ethylene action, slowed yellowing of broccoli at $12{ }^{\circ} \mathrm{C}$, which concurs with the results of $\mathrm{Ku}$ and Wills (1999) and Fan and Mattheis (2000) who tested the effects of $1-\mathrm{MCP}$ at $20^{\circ} \mathrm{C}$ and $10{ }^{\circ} \mathrm{C}$, respectively.

Low concentrations of ozone also have been reported to slow broccoli senescence possibly by the reduction of ethylene concentrations in the storage atmosphere. Skog and Chu (2001) found that $40 \mathrm{~nL} \cdot \mathrm{L}^{-1}$ ozone eliminated ethylene in the storage atmosphere and slowed broccoli yellowing when broccoli was stored in chambers containing ethylene-producing apple fruit. In our study, continuous exposure of broccoli to $200 \mathrm{~nL} \cdot \mathrm{L}^{-1}$ ozone only slightly reduced the rate of yellowing, which may be due to low ambient ethylene concentrations. The reduction of yellowing at $700 \mathrm{~nL} \cdot \mathrm{L}^{-1}$ ozone may be related to the inhibition of chlorophyll degrading enzymes and/or the induction of antioxidants that can protect chlorophyll. Zhuang et al. (1995) suggest that lipid peroxidation may be responsible for chlorophyll loss during broccoli senescence. As a response to ozone, broccoli may increase levels of antioxidant chemicals and enzymes which could slow chlorophyll loss (Castillo and Greppin, 1988). 
Mold growth was inhibited by 200 and $700 \mathrm{~nL} \cdot \mathrm{L}^{-1}$ ozone. Gaseous ozone has been reported to reduce fungal mycelium growth on a variety of stored commodities including citrus, peaches, grapes, onions, and carrots (Hildebrand et al., 2001; Palou et al., 2002; Song et al., 2000).

Exposure to $700 \mathrm{~nL} \cdot \mathrm{L}^{-1}$ ozone caused increased weight loss resulting in desiccation of flower buds. Weight loss is stimulated by ozone in plums (Crisosto et al., 1993), peaches (Palou et al., 2002), and cranberries (Norton et al., 1968). In addition, ozone caused increased shriveling of cucumbers during storage (Skoog and Chu, 2001). This apparent increase in water loss may be caused by cuticle degradation by ozone, which occurred in both plums and cranberries (Crisosto et al., 1993; Norton et al., 1968). Sarig et al. (1996) found ozone to cause microscopic vein-like cracks in the cuticle of grapes. Ozone induced membrane damage, which causes increased membrane leakiness, could also contribute to enhanced water loss (Tingey and Taylor, 1982).

The increased $\mathrm{CO}_{2}$ production during the first $5 \mathrm{~d}$ reflects stimulated metabolism associated with the senescence of broccoli, as reported by Tian et al. (1997). In 0 and $200 \mathrm{~nL} \cdot \mathrm{L}^{-1}$ ozone, the 1-MCP treatment reduced the rate of $\mathrm{CO}_{2}$ production similar to the reduction in respiration rate by $1-\mathrm{MCP}$ reported by Fan and Mattheis (2000). The reduction in respiration results from the blocking of ethylene action, which plays an important role in stimulating senescence of broccoli florets (Tian et al., 1994). In contrast, the $700 \mathrm{~nL} \cdot \mathrm{L}^{-1}$ ozone treatment stimulated $\mathrm{CO}_{2}$ and ethylene production by broccoli florets, which suggests that this high concentration of ozone caused stress resulting in physiological damage. This was confirmed by the appearance of visible damage seen as enhanced weight loss and browning of the floret stem ends. Treatment with $200 \mathrm{~nL} \cdot \mathrm{L}^{-1}$ ozone with or without $1-\mathrm{MCP}$ did not stimulate ethylene production or cause visable damage in broccoli florets.

The decline in chlorophyll fluorescence $\left(\mathrm{F}_{\mathrm{v}} / \mathrm{F}_{\mathrm{m}}\right)$ paralleled the decline in hue angle. Treatments with 1-MCP slowed yellowing and maintained chlorophyll fluorescence. A similar relationship between the decrease in chlorophyll fluorescence and yellowing was reported by Toivonen and DeEll (1998). Chlorophyll fluorescence has been used as an indicator of physiological stress and to identify stress resistant cultivars (DeEll et al., 1999; Song et al., 1997, 2001). When broccoli florets were exposed to $700 \mathrm{~nL} \cdot \mathrm{L}^{-1}$ ozone, a rapid decrease in chlorophyll fluorescence $\left(\mathrm{F}_{\mathrm{v}} / \mathrm{F}_{\mathrm{m}}\right)$ was observed after $1 \mathrm{~d}$ of treatment, indicating that stress was caused by the high concentration of ozone. The sharp decrease in fluorescence coincided with an increase in respiration and ethylene production. The decline in fluorescence resulted from an increase in $\mathrm{F}_{\mathrm{o}}$ as well as a decrease in $\mathrm{F}_{\mathrm{m}}$. The mechanism by which ozone increased the $\mathrm{F}_{\mathrm{o}}$ value is unknown, but this phenomenon has also been found in bean leaves exposed to ozone (Guidi et al., 2000). When spinach leaves were treated with ozone in our laboratory, a decrease in $\mathrm{F}_{\mathrm{v}} / \mathrm{F}_{\mathrm{m}}$ caused by an increase in $\mathrm{F}_{\mathrm{o}}$ and relatively stable $\mathrm{F}_{\mathrm{m}}$ value was also observed (unpublished observation). A decrease of both $\mathrm{F}_{\mathrm{o}}$ and $\mathrm{F}_{\mathrm{m}}$ contributed to a decrease in fluorescence during apple fruit ripening and senescence (Song et al., 1997). Because of the high reactivity of ozone, it cannot penetrate to the chloroplast. However, other reactive species/products resulting from ozone-induced oxidative stress may affect the photosynthetic apparatus, particularly at the membrane level, which is reflected in the decline in chlorophyll fluorescence (Heath, 1994).

Monitoring broccoli volatiles also provided an indication of overall quality as well as senescence or stress. Dimethyl disulfide and DMTS are associated with senescence and physiological injury of broccoli, and contribute to off-odors (Forney et al., 1991; Forney and Jordan, 1998). In our study, an increase of DMDS coincided with yellowing and a decrease in chlorophyll fluorescence. Treatment with 1-MCP reduced the production of DMDS and DMTS, probably as a result of slowing senescence. Exposure to $700 \mathrm{~nL} \cdot \mathrm{L}^{-1}$ ozone without $1-\mathrm{MCP}$ also reduced DMDS and DMTS production after $12 \mathrm{~d}$, which paralleled a decrease in respiration, ethylene production, and chlorophyll fluorescence, indicating that this reduction in volatile production may have been the result of cellular damage caused by the high ozone concentration.

The application of 1-MCP on fresh broccoli holds promise for delaying yellowing and extending shelf life. Application of 200 $\mathrm{nL} \cdot \mathrm{L}^{-1}$ ozone showed only a slight benefit in reducing yellowing and surface molds, while $700 \mathrm{~nL} \cdot \mathrm{L}^{-1}$ treatments were injurious. Additional work is needed to determine if other ozone concentrations or durations of exposure could further improve the storage life of broccoli.

\section{Literature Cited}

Barth, M.M., E.L. Kerbel, S. Broussard, and S.J. Schmidt. 1993. Modified atmosphere packaging protects market quality in broccoli spears under ambient temperature storage. J. Food Sci. 58:1070-1072.

Bastrash, S., J. Makhlouf, F. Castaigne, and C. Willemot. 1993. Optimal controlled atmosphere conditions for storage of broccoli florets. J. Food Sci. 58:338-341,360.

Castillo, F.J. and H. Greppin. 1988. Extracellular ascorbic acid and enzyme activities related to ascorbic acid metabolism in Sedum album L. leaves after ozone exposure. Environ. Expt. Bot. 28:231-238.

Crisosto, C.H., W.A. Retzlaff, L.E. Williams, T.M. DeJong, and J.P. Zoffoli. 1993. Postharvest performance evaluation of plum (Prunus salicina Lindel., 'Casselman') fruit grown under three ozone concentrations. J. Amer. Soc. Hort. Sci. 118:497-502.

DeEll, J.R., O. van Kooten, R.K. Prange, and D.P. Murr. 1999. Applications of chlorophyll fluorescence techniques in postharvest physiology, p. 69-108. In: J. Janick (ed.). Horticultural reviews. vol. 23. Wiley, New York.

Fan, X. and J.P. Mattheis. 2000. Yellowing of broccoli in storage is reduced by 1-methylcyclopropene. HortScience. 35:885-887.

Forney, C.F. 1995. Hot water dips extend the shelf life of fresh broccoli. HortScience 30:1054-1057.

Forney, C.F. and M.A. Jordan. 1998. Induction of volatile compounds in broccoli by postharvest hot-water dips. J. Agr. Food Chem. 46: 5295-5301.

Forney, C.F., J.P. Mattheis, and R.K. Austin. 1991. Volatile compounds produced by broccoli under anaerobic conditions. J. Agr. Food Chem. 39:2257-2259.

Genstat 5 Committee. 1993. Genstat 5 Release 3 reference manual. Clarendon Press, Oxford, U.K.

Gnanasekharan, V., R.L. Shewfelt, and M.S. Chinnan. 1992. Detection of color changes in green vegetables. J. Food Sci. 57:149-154.

Guidi, L., R. Di Cagno, and G.F. Soldatini. 2000. Screening of bean cultivars for their response to ozone as evaluated by visible symptoms and leaf chlorophyll fluorescence. Environ. Pollution 107:349-355.

Heath, R.L. 1994. Possible mechanisms for inhibition of photosynthesis by ozone. Photosyn. Res. 39:439-451.

Hildebrand, P.D., J. Song, C.F. Forney, W.E. Renderos, and D.A.J. Ryan. 2001. Effects of corona discharge on decay of fresh fruits and vegetables. Acta Hort. 553:425-426.

Kim, J.G., A.E. Yousef, and S. Dave. 1999. Application of ozone for enhancing the microbiological safety and quality of foods: A review. J. Food Protection 62:1071-1087.

King, G.A. and S.C. Morris. 1994. Physiological changes of broccoli during early postharvest senescence and through the preharvest-postharvest continuum. J. Amer. Soc. Hort. Sci.119:270-275.

Ku, V.V.V. and R.B.H. Wills. 1999. Effect of 1-methylcyclopropene on 
the storage life of broccoli. Postharvest Biol. Technol. 17:127-132.

Lipton, W.J. and C.M. Harris. 1974. Controlled atmosphere effects on market quality of stored broccoli (Brassica oleracea L. Italica group). J. Amer. Soc. Hort. Sci. 99:200-205.

Norton, J.S.,A.J. Charig, and I.E. Demoranville. 1968. The effect of ozone on storage of cranberries. Proc. Amer. Soc. Hort. Sci. 93:792-796.

Page, T., G. Griffiths, and V. Buchanan-Wollaston. 2001. Molecular and biochemical characterization of postharvest senescence in broccoli. Plant Physiol. 125:718-727.

Palou, L., C.H. Crisosto, J.L. Smilanick, J.E. Adaskaveg, and J.P. Zoffoli. 2002. Effects of continuous 0.3 ppm ozone exposure on decay development and physiological responses of peaches and table grapes in cold storage. Postharvest Biol. Technol. 24:39-48.

Pell, E.J., C.D. Schlagnhaufer, and R.N. Arteca. 1997. Ozone-induced oxidative stress: Mechanisms of action and reaction. Physiol. Plant. 100:264-273.

Ryall, A.L. and W. J. Lipton. 1979. Handling, transportation and storage of fruits and vegetables. vol. 1. Vegetables and melons. $2^{\text {nd }}$ ed. AVI, Westport, Conn.

Sarig, P., T. Zahavi, Y. Zutkhi, S. Yannai, N. Lisker, and R. Ben-Arie. 1996. Ozone for control of post-harvest decay of table grapes caused by Rhizopus stolonifer. Physiol. Mol. Plant Pathol. 48:403-415.

Skog, L.J. and C.L. Chu. 2001. Effect of ozone on qualities of fruits and vegetables in cold storage. Can. J. Plant Sci. 81:773-778.

Song, J., W. Deng, and R.M. Beaudry. 1997. Changes in chlorophyll fluorescence of apple fruit during maturation, ripening, and senescence. HortScience. 32:891-896.
Song, J., L. Fan, C.F. Forney, and M.A. Jordan. 2001. Using volatile emissions and cholorophyll fluorescence as indicators of heat injury in apples. J. Amer. Soc. Hort. Sci. 126:771-777.

Song, J., L. Fan, P.D. Hildebrand, and C.F. Forney. 2000. Biological effects of corona discharge on onions in a commercial storage facility. HortTechnology 10:608-612.

Tian, M.S., C.G. Downs, R.E. Lill, and G.A. King. 1994. A role for ethylene in the yellowing of broccoli after harvest. J. Amer. Soc. Hort. Sci. 119:276-281.

Tian, M.S., T. Islam, D.G. Stevenson, and D.E. Irving. 1997. Color, ethylene production, respiration, and compositional changes in broccoli dipped in hot water. J. Amer. Soc. Hort. Sci. 122:112-116.

Tingey, D.T. and G.E. Taylor, Jr. 1982. Variation in plant response to ozone: A conceptual model of physiological events, p. 113-138. In: M.H. Unsworth and D.P. Ormrod (eds.). Effects of gaseous air pollution in agriculture and horticulture. Butterworth Scientific, London.

Toivonen, P.M.A. and J.R. DeEll. 1998. Differences in chlorophyll fluorescence and chlorophyll content of broccoli associated with maturity and sampling section. Postharvest Biol. Technol. 14:61-64.

Wang, C.Y. and H.W. Hruschka. 1977. Quality maintenance in polyethylene-packaged broccoli. U.S. Dept. Agr. Mktg. Res. Rpt. 1085.

Wills, R.B.H., V.V.V. Ku, D. Shothet, and G.H. Kim. 1999. Importance of low ethylene levels to delay senescence of non-climacteric fruit and vegetables. Austral. J. Expt. Agr. 39:221-224.

Zhuang, H., D.F. Hildebrand, and M.M. Barth. 1995. Senescence of broccoli buds is related to changes in lipid peroxidation. J. Agr. Food Chem. 43:2585-2591. 